\title{
Joseph Warren: a discussion of his life and analysis of his death
}

\author{
${ }^{*}$ Ryan Holland, BA, ${ }^{1}$ Victor M. Sabourin, MD, ${ }^{1}$ Chirag D. Gandhi, MD, ${ }^{1-3}$ Peter W. Carmel, MD, ${ }^{1}$ and \\ Charles J. Prestigiacomo, MD'1-3
}

\begin{abstract}
Departments of ${ }^{1}$ Neurological Surgery, ${ }^{2}$ Radiology, and ${ }^{3}$ Neurology and Neuroscience, Rutgers New Jersey Medical School, Newark, New Jersey
\end{abstract}

\begin{abstract}
As his fellow soldiers ran past him, Joseph Warren stood bravely on Bunker Hill. It was June 17, 1775, and British troops were fighting the colonists in one of the early battles of the American Revolution. The British had already attempted two major assaults that day, and the third would end with Warren's death. He was a medical doctor, public figure, and general who spent his life and last living moments fighting for freedom for the American colonists.

After the battle, there was much confusion about what had happened to Joseph Warren. Some thought he had survived the battle; other accounts differed on how exactly he had died. The details of the events on Bunker Hill remained a mystery until the following year, when Paul Revere helped identify Warren's body by the false teeth that had been implanted years earlier. Warren's remains showed that his head had been struck by a bullet.

Analysis of the skull helped to sift through the differing tales of Warren's death and thus unveil the truth about what occurred that day. The smaller bullet wound in the left maxilla suggests that he was not shot while retreating with the rest of the soldiers. The larger exit wound in the right occiput illustrates that the bullet's trajectory crossed the midline of the brain and most likely injured the brainstem. Therefore, contrary to rumors that circulated at the time, Joseph Warren most likely was killed instantly at the Battle of Bunker Hill while heroically facing his enemy.

http://thejns.org/doi/abs/10.3171/2015.3.FOCUS1564
\end{abstract}

KEY WORDS Joseph Warren; American Revolution; neurosurgical history; head injury; Battle of Bunker Hill

$\mathrm{T}$ HE tension in Boston's Old South Church was palpable the morning of March 6, 1775. It was the anniversary of the Boston Massacre, and sitting in the front pews were British officers, possible perpetrators of the killings. ${ }^{9}$ The audience at this public meeting waited in earnest to hear from Dr. Joseph Warren, a public figure who was widely known to favor American independence from the British. To avoid a possible confrontation with the officers and their supporters, the orator entered through a window in the back of the pulpit. ${ }^{9}$ As silence filled the room, Warren began: ${ }^{9}$

That personal freedom is the natural right of every man, and that property, or an exclusive right to dispose of what he has honestly acquired by his own labor, necessarily arises therefrom, are truths which common sense has placed beyond the reach of contradiction; and no man or body of men can, without being guilty of flagrant injustice, claim a right to dis- pose of the persons or acquisitions of any other man or body of men, unless it can be proved that such a right had arisen from some compact between the parties in which it has been explicitly and freely granted.

The audience, appreciating his sentiments, erupted in applause. ${ }^{9}$ Warren continued to speak on the importance of freedom in front of the British officers who enforced the perceived unjust laws Britain had enacted for the colonies. It became clear in that church that the colonists were becoming defiant. ${ }^{9}$ A few years after Warren's speech, a similar defiance would culminate in the beginning of the American Revolutionary War.

Joseph Warren (Fig. 1) was born on June 11, 1741, in Roxbury, Massachusetts. He was the eldest child of Joseph, a well-known apple farmer, and Mary Warren. ${ }^{9}$ Shortly after the death of his father when he was 14, Warren started his undergraduate work at Harvard College. In 1762, he

SUBMITTED February 28, 2015. ACCEPTED March 26, 2015 INCLUDE WHEN CITING DOI: 10.3171/2015.3.FOCUS1564.

DISCLOSURE The authors report no conflict of interest concerning the materials or methods used in this study or the findings specified in this paper.

* Mr. Holland and Dr. Sabourin contributed equally to this work. 


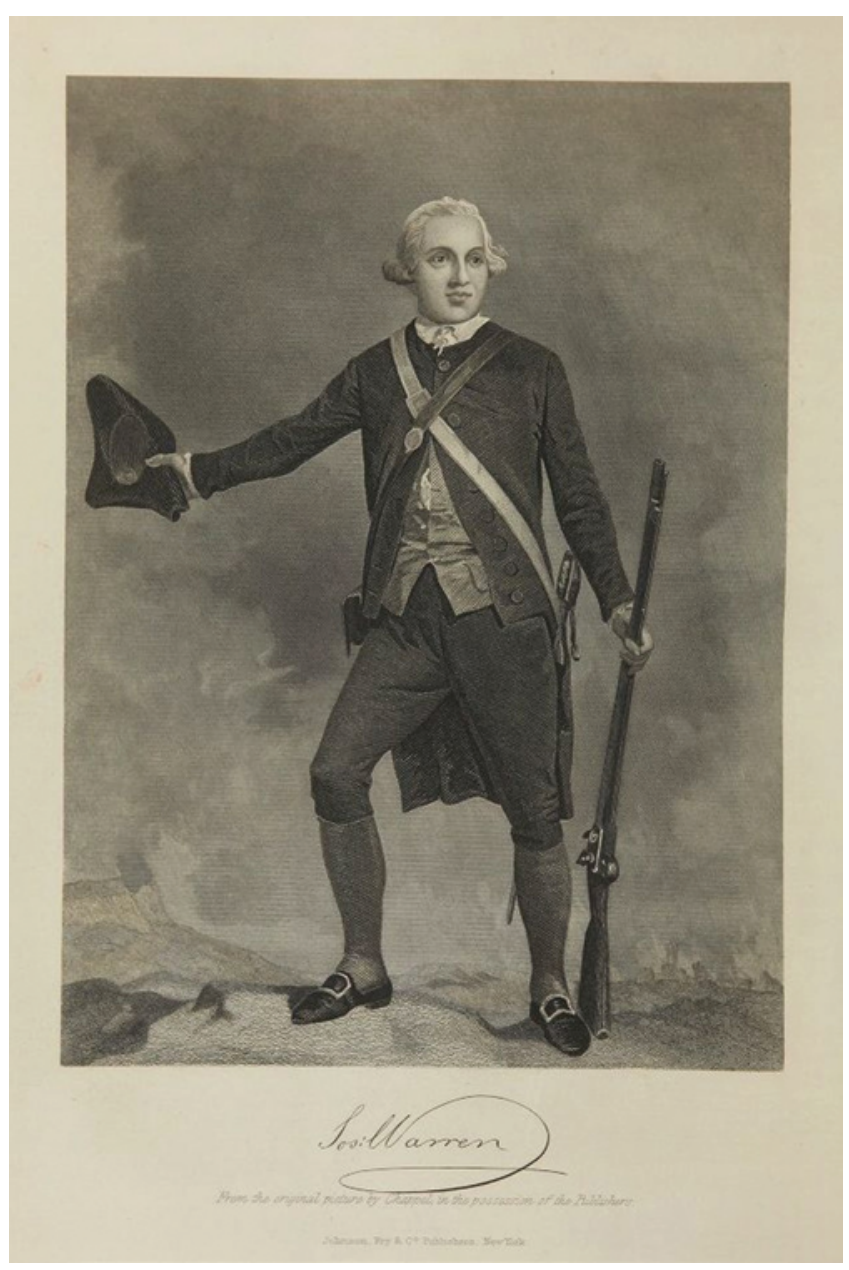

FIG. 1. Joseph Warren (1741-1775). Duyckinck EA, Chappel A (illustrator): National Portrait Gallery of Eminent Americans, Vol. 1. New York: Johnson, Fry \& Company, 1861. Public domain.

earned his Master of Arts degree from the institution. ${ }^{9}$ At school, Joseph was known to be a man of "superior talents, gentle manners, and a frank, independent, and fearless character." 5 At Harvard, Warren joined the Anatomical Club, also known as the Spunkers Club, along with other aspiring physicians. As a member of this club, he had to surreptitiously retrieve cadavers so that he and his fellow students could study their anatomy. ${ }^{7}$ However, there are no official records of the activities of this club, which was most likely due to the fact that the acquisition of corpses for study was illegal and viewed by many as immoral. ${ }^{7}$

\section{Medical Career}

Soon after graduating from Harvard, Warren had the opportunity to pursue a career as a physician. Wealthier families were able to send their sons to Europe to study medicine, but Warren was not able to do this and became an apprentice under a practicing physician in the colonies. He studied for 2 years under Dr. James Lloyd, a physician with an excellent reputation in London and Boston.7,12 After completing his apprenticeship, Warren began seeing patients in Roxbury. As a courtesy to his hometown, he did not collect fees for these services. ${ }^{7}$ In many seri- ous medical cases, people would preferentially seek out known physicians to perform surgeries. ${ }^{7}$ Therefore, Warren was competent in medicine, surgery, and obstetrics. He regularly attended deliveries and sometimes even performed limb amputations. ${ }^{7}$

At 23, he moved his practice to Boston where he met his future friend, John Adams, as his patient. ${ }^{7,9}$ During the 12 years he practiced medicine, Warren saw around 1500 patients. Dr. Warren did not discriminate and took care of everyone from the wife of John Adams to unnamed slaves. ${ }^{7}$ Many of these patients came to Warren for small pox inoculations. He was often willing to provide these vaccinations free of charge. ${ }^{7}$ Warren was known to be a good preceptor, and some of his students, including his brother John, later founded Harvard Medical School.? During his career, he wrote under a pen name to argue for the creation of a professional medical society. He wanted to start an organization of Massachusetts physicians to improve the education of young doctors and discourage unqualified practitioners. Years after his death, the Massachusetts Medical Society was officially founded, but the society began to be organized by Warren and his peers decades earlier.

\section{Political and Social Life}

By age 26, Warren firmly believed in the independence of America, writing in the Boston Gazette that "America must and will be free; the contest may be severe, the end will be glorious." "Warren was an enthusiast for liberty, but appreciated the necessity of lawfulness. He wanted the colonies to have a government based on the will and power of the people. Warren believed that government should have adequate authority to protect the rights of citizens and their property. ${ }^{9}$

Although he was adamant that the British were wrong, he held that it would be inappropriate to use violence to protest. The following year, Warren spoke against such measures in public meetings held in Boston. Britain considered these peaceful meetings designed to address grievances as treasonous. Therefore, local political clubs were used to safely discuss politics. Warren used these private gatherings to plan town meetings and discuss other measures. ${ }^{9}$

These discussions were often reactions to recent British legislation. For instance, in 1774 Parliament responded to the Tea Party by writing statutes that closed the port of Boston, ended many town meetings, and organized a system for sending Americans to Britain to stand trial. These statutes were known as the Coercive Laws in London, but the Colonies knew them as the Intolerable Acts. ${ }^{6}$ In response, Warren drafted a set of resolutions known as the "Suffolk Resolves." These Suffolk Resolves claimed that the Intolerable Acts were unjust and recommended retaliation against Britain. He also urged the people of Massachusetts to form their own government and to fight in its defense if needed. ${ }^{6}$ Other towns followed suit and printed their own resolves, further distancing the colonies from Great Britain. ${ }^{6}$

The Committee of Correspondence was created to protect the rights of the colonists, publish papers, and create free dialogue between towns. ${ }^{7}$ Warren was a member of the Boston chapter of this committee when he sent Paul 
Revere and William Dawes on their famous Midnight Ride to alert the militia at Lexington and Concord to prepare for battle. ${ }^{9}$ Warren gave Revere a letter that night that informed the town leaders that General Gage would likely reach Concord the following day. In actuality, Gage was not yet ready to march; however, Warren's letter gave the colonists time to move military supplies out of Concord and into the surrounding communities. These acts of rebellion were especially dangerous because the British had spies in Boston. In fact, Paul Revere's trip was soon reported to General Gage. The report mentioned that " $P$

R____ arrived at Concord" carrying a letter from Warren shortly before the supplies were moved. ${ }^{6}$

In 1775, Warren was both the chairman of the Committee of Safety and president of the Massachusetts Provincial Congress.

Warren enjoyed an active social, as well as professional and political, life. ${ }^{9}$ For example, in 1761 he was accepted into one of the two Masonic lodges in Boston. One of them, St. John's Lodge, was a then-modern Freemason lodge affiliated with the Grand Lodge in England. Warren preferred to join the newly established lodge, St. Andrew's, which was part of the ancient society, and not associated with the more modern organization. The St. John's Lodge contained more conservative and wealthy members, while St. Andrew's included revolutionaries such as John Hancock and Paul Revere. ${ }^{12}$ Warren left St. Andrew's Lodge for unknown reasons, but was readmitted unanimously as a member in 1765. On March 3, 1772, he received a letter from the leader of the Freemasons, the Grand Master Earl of Dumfries, honoring him with the title of Grand Master over the Continent of America. ${ }^{13}$

John Hancock and Samuel Adams left Boston in 1775 to attend the Provincial Congress in Concord. While they were away, Warren's office was used to discuss the rumors and information that were circulating around town. ${ }^{6}$ At that time in Boston, there was a new rumor or alarm nearly every hour. ${ }^{6}$ Warren would hear the rumors, determine if the information was legitimate, and then act on them if appropriate. Warren determined the legitimacy of each rumor by using his confidential informer who had connections to the uppermost levels of the British command. ${ }^{6}$ Warren was the only person who knew the identity of this informant, and he faithfully kept the identity of the informant a secret even after his death. To this day, although there have been theories of who it could have been, the identity of the informant remains unknown. ${ }^{6}$

\section{Military Career}

Although successful in his medical and political endeavors, Warren soon concentrated less effort on these and instead began focusing on his military career. ${ }^{9}$ In April 1775, he missed a Committee of Safety meeting, saw fewer patients, and began exercising regularly. ${ }^{9} \mathrm{He}$ soon earned the respect and admiration of his fellow soldiers and officers. It was said of Warren "that he was perhaps the most active man in the field" and that "the people were delighted with his cool, collected bravery, and already considered him as a leader whose gallantry they were to admire, and in whose talents they were to confide." ${ }^{\prime}$ His successful medical practice and handling of smallpox out- breaks was so well known by the end of his short medical career that he was asked to become Surgeon General of the Army. After declining the offer, he was offered the rank of Major General and accepted. ${ }^{5}$

The Battle of Bunker Hill was fought on the Charlestown peninsula in Boston, Massachusetts, on June 17, 1775.,9 The Charlestown neighborhood contained most of the revolutionists' powder reserves that were needed for weaponry. Although the battle is formally named after Bunker Hill, most of the battle actually took place on the adjacent Breed's Hill. ${ }^{4}$ Although they technically won the battle, the British had never faced more accurate effective fire. ${ }^{3}$ Out of the 4000 Redcoats who began the battle, 226 were killed and 828 wounded. ${ }^{3}$ There were also more officers killed than in prior engagements. Conversely, the Colonial troops incurred only 140 deaths and 271 injuries, and had 30 men captured. Beginning with fewer soldiers, the Colonial Army managed to sustain fewer casualties than the British. ${ }^{3}$

During the first attempt to take the hill, the Continental Army stood bravely and fired at the British. Although this first defensive maneuver was successful, it cost the lives of many soldiers. The British retreated, but the colonists knew they could not continue fighting in this manner because they were unable to reposition the artillery that was around Cambridge. ${ }^{15}$ Eventually, officers began to abandon the battle, which motivated other soldiers to leave their cannon and run from the action. ${ }^{15}$ Colonel Prescott of the Continental Army ordered an official retreat during the third attempt by the British to take the hill. Although Warren held the rank of Major General, because he had not received his commission, he served as a volunteer during the battle and did not take command over General Putnam or Colonel Prescott. ${ }^{9}$ Instead he asked General Putnam where the battle would be fiercest and when Putnam named the redoubt, Warren then positioned himself at the redoubt on Breed's Hill. ${ }^{9}$ Warren chose to stand and fight instead of running away from the hill. ${ }^{15}$ Fig. 2 displays a map of the Battle of Bunker's Hill from 1775. Figure 3 is a modern map of the Battle of Bunker Hill (a more detailed map is available from the Library of Congress at http:// lccn.loc.gov/2005628234).

\section{Rumors of Warren's Death}

The following morning, Joseph Warren's brother John heard different tales of his brother's condition. The stories included Joseph being dead on the battlefield, wounded, or alive and well. Even the accounts of Warren's death differed. One popular explanation was that he was shot in the back of the head and held his hand there before dying. ${ }^{9}$ Another account stated that Warren was shot in the forehead. ${ }^{5}$ Yet another had Warren addressing his men after being shot. The printed piece "Eulogium on Warren" claimed that he gave one final inspirational speech to his men after being wounded. The truth of what occurred that day was unknown at the time. ${ }^{9}$ However, by Monday, the second day after the battle, the colonial government recognized that Warren was dead. The Provincial Congress elected a new president "in the room of the Hon. Joseph Warren, Esq., supposed to be killed in the last battle."9

On March 21 of the following year, Paul Revere trav- 


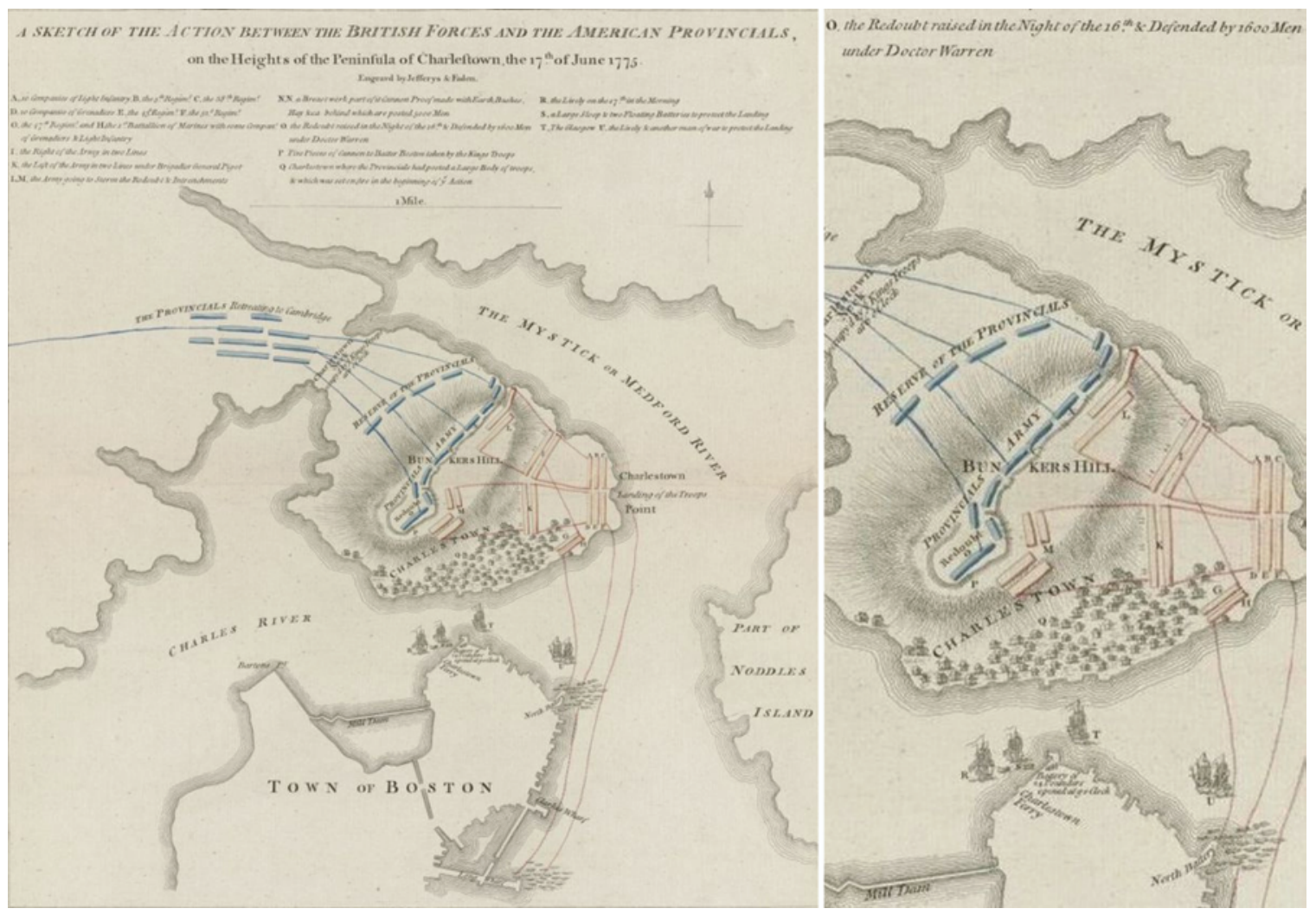

FIG. 2. Left: A sketch of the action between the British forces and the American provincials, on the heights of the peninsula of Charlestown, the 17th of June 1775. Right: Close-up of the Battle of Bunker's Hill. Jefferys \& Faden, 1775. (Map incorrectly labels Breed's Hill as Bunker's Hill.) Map reproduction courtesy of the Norman B. Leventhal Map Center at the Boston Public Library. Published with permission.

eled to Charlestown to recover Joseph Warren's body. After several days, the body was exhumed and noted to be grossly disfigured. A British lieutenant had previously uncovered Warren, spit in his face, and decapitated his corpse. The remains were recognized as Warren by the two artificial teeth and the silver wire that Revere had implanted shortly before Warren's death. ${ }^{11}$ An analysis of Warren's skull and its injuries could be used to reconstruct the events and potentially filter the various accounts of Warren's last moments and can also provide insights into the neurological injury that he sustained., ${ }^{1,2,14}$

\section{Analysis of Head Injury}

The bullet, a musket ball, left two distinct wounds in Warren's skull (Figs. 4-6). ${ }^{10}$ By comparing the size, shape, and location of the two wounds, the bullet's path can be estimated. Exit wounds are normally larger and of a more irregular shape than entrance wounds created by a slug. ${ }^{14}$ Entrance wounds also tend to be "cleaner," having a more regular and round configuration, while exit wounds have an irregular, shattered appearance. Although the velocity of the bullet decreases after penetrating bone, it flattens, becomes unstable (known as tumbling), and mushrooms, which accounts for the larger exit wound. ${ }^{14}$ In accordance with these principles, the bullet most likely entered the left maxilla (Fig. 4) and exited through the right side of the occipital bone (Fig. 5). Thus, although his fellow soldiers were retreating to safety, Warren held the line and was killed while facing his enemy. Figure 7 is a depiction of Warren's death at the Battle of Bunker's Hill.

Thus the bullet's trajectory can be used to reveal which version of Warren's death was accurate. The severity of a gunshot wound to the skull depends upon which part of the brain sustains damage. Bullets penetrating multiple lobes of the brain or entering the ventricular system are particularly lethal. ${ }^{1}$ Poorer outcomes are associated with extensive bullet tracks, those trajectories that cross the midline structures of the brain, or those involving the brainstem. ${ }^{2}$ Because the entry wound is on the left and the exit wound on the right, the bullet clearly traversed the midline. In doing so, the bullet either directly or through secondary injury due to cavitation effects, severely injured the brainstem. The ventricular system may have been struck as well. With all of these facts in mind, Warren most likely died instantly. A study of Joseph Warren's remains and forensic analysis of injuries undertaken on his skull has therefore helped debunk some of the myths surrounding his actions on Breed's Hill. Joseph Warren was not shot in the forehead nor in the back of the head as some reports suggested. He died instantly and therefore gave no final speech to his men before his death.

\section{Conclusions}

Warren was respected by both the Americans and the 


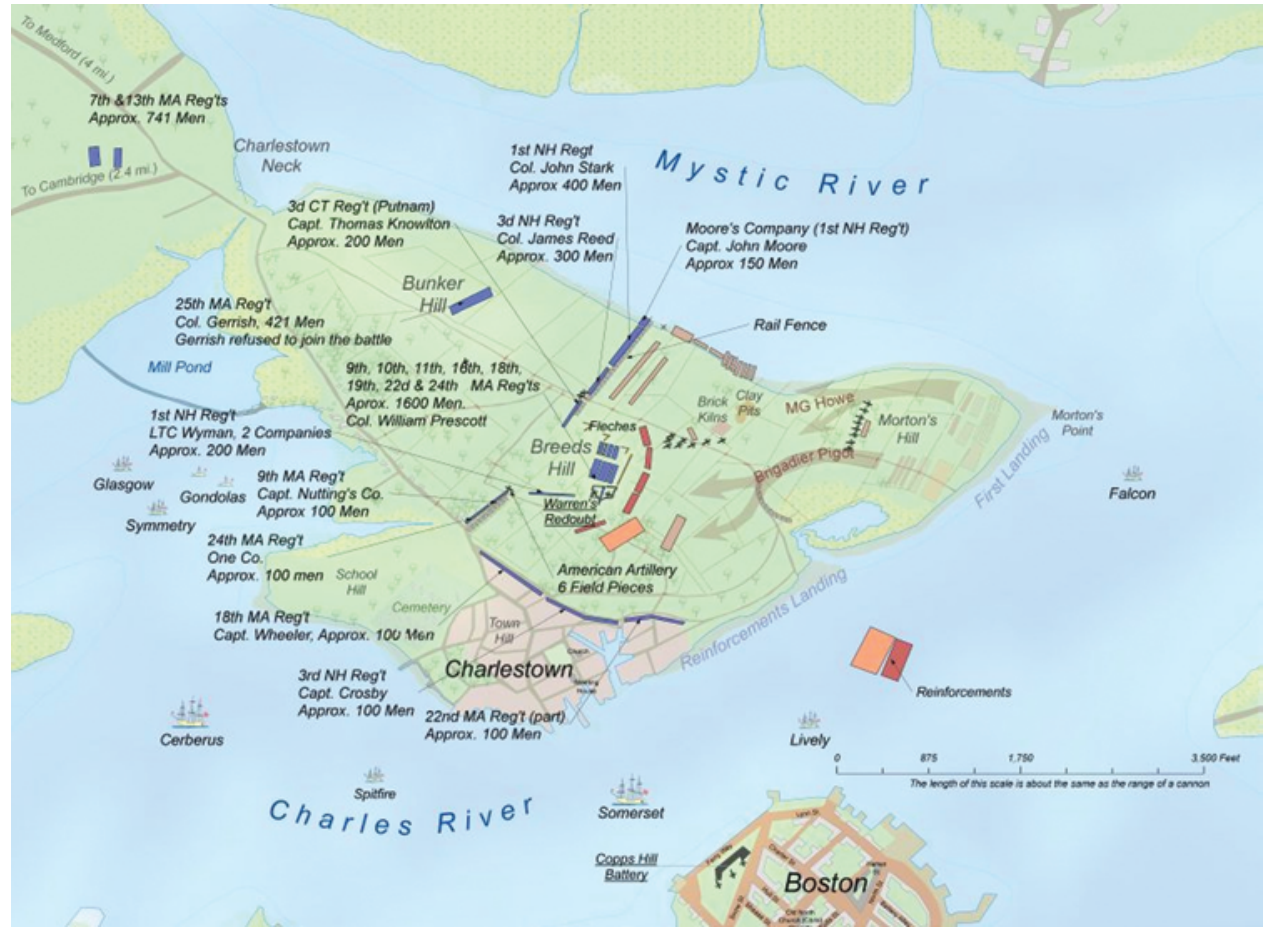

FIG. 3. The Battle of Bunker's Hill. Map depicts the location of Warren's Redoubt. Charlie Frye, Chief Cartographer, Esri Inc. Published with permission.

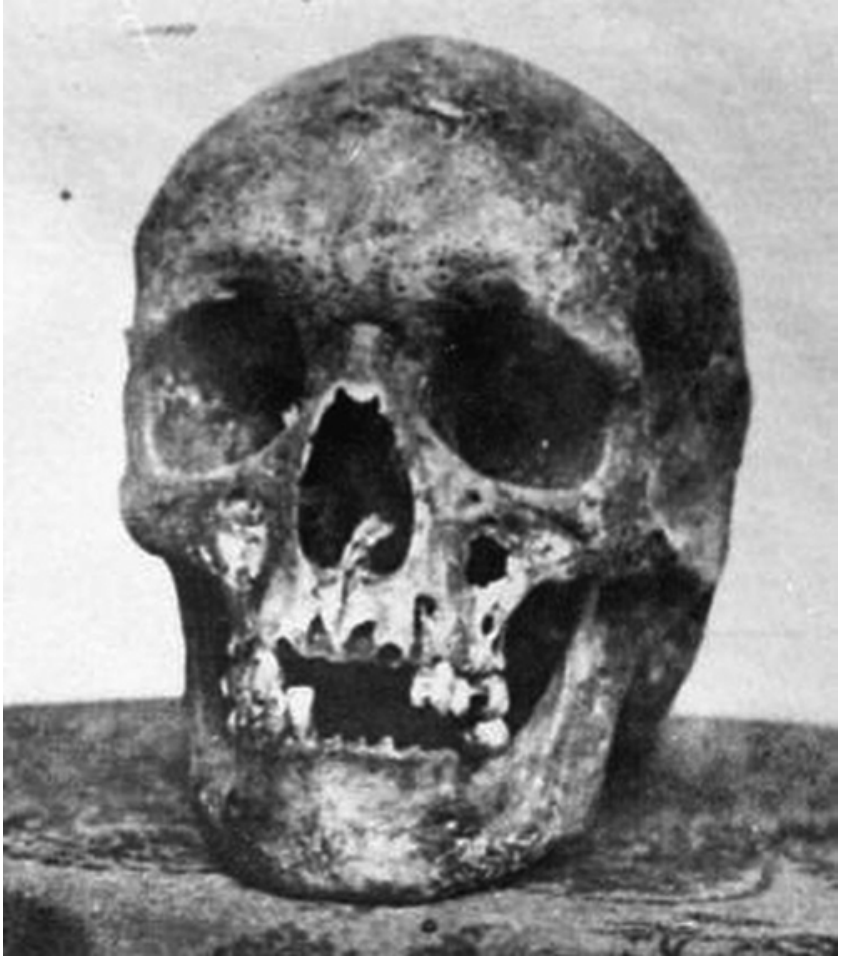

FIG. 4. Anterior view of Warren's skull. ${ }^{10}$ The entrance wound can be seen in the left maxilla. Photo taken by Dr. Lester Luntz and originally published in Handbook for Dental Identification: Techniques in Forensic Dentistry. Published with permission.
British and his loss was mourned by all. Even British General Howe could not believe the report he had received of Dr. Warren's death. When confirmed, he later stated that Dr. Warren's death was equal to the death of 500 men. ${ }^{8}$ If he had not perished on Bunker's Hill, Warren most likely would have become more influential within the American political, military, and medical fields. Because of his popularity and experience as head of the Freemasons and

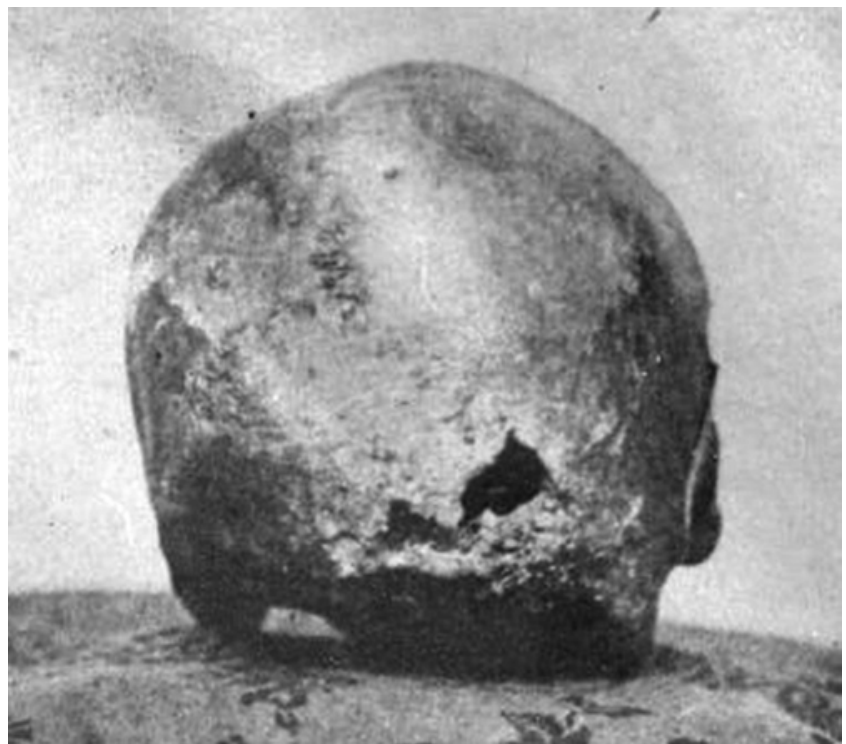

FIG. 5. Posterior view of Warren's skull. ${ }^{10}$ The exit wound is in the right occiput. Photo taken by Dr. Lester Luntz and originally published in Handbook for Dental Identification: Techniques in Forensic Dentistry. Published with permission. 


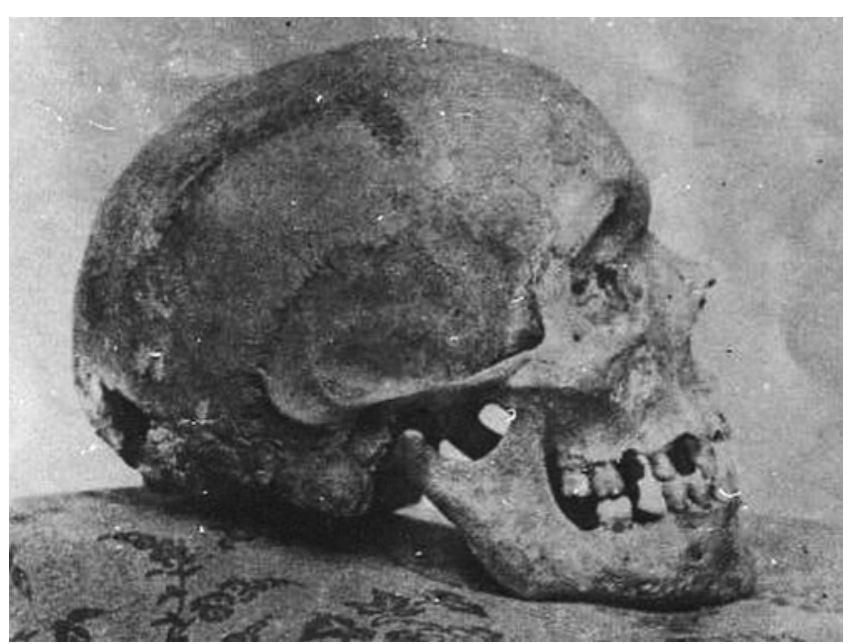

FIG. 6. Right sagittal view of Warren's skull..$^{10}$ Photo taken by Dr. Lester Luntz and originally published in Handbook for Dental Identification: Techniques in Forensic Dentistry. Published with permission.

several political committees, it is reasonable to assume that Warren would have played a prominent role in the early years of the United States government. Whether as a prominent political official or in another position, Warren would have tried to create a country founded on his ideals of liberty. Although he died shortly after accepting the rank of Major General, had he survived, Warren might have played a large role in the Continental Army, helping to free the Colonies from the British Crown. Given his interests in medicine, had he not been killed, it is also reasonable to speculate whether Joseph Warren might have helped his brother, John, in the establishment of Harvard Medical School. Another possible path of Warren's life would have been accepting the previous offer of becoming a Surgeon General. Joseph Warren's life, which he spent using his interests in medicine, politics, and the military to help his community and country, tragically ended too soon.

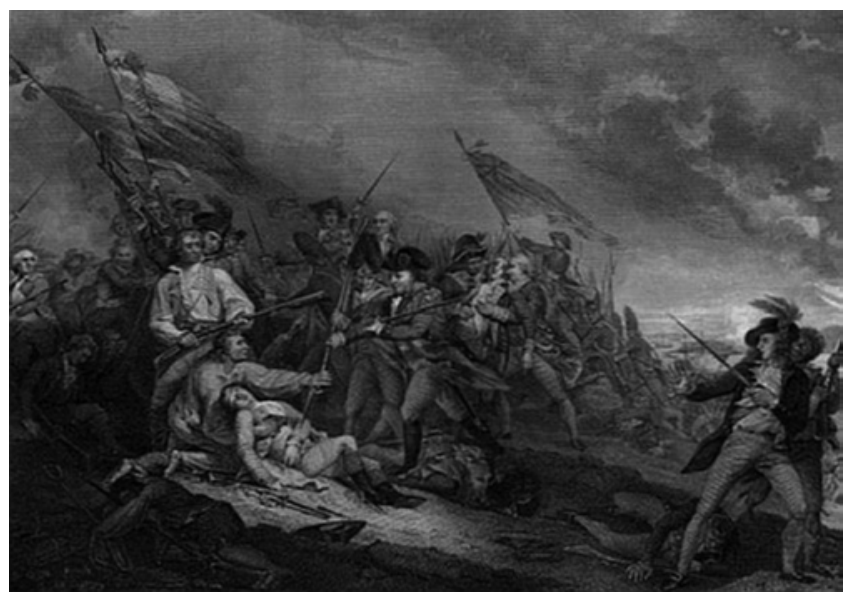

FIG. 7. Warren's Death at the Battle of Bunker's Hill, painting by John Trumbull. Source: Hinton JH, Knapp SL, Choules JO: The History and Topography of the United States of North America. Boston: Samuel Walker, 1852. Public domain.

\section{Acknowledgment}

We would like to thank Derek Beck for his help in contacting the Luntz family. He is currently working on a history of the American Revolution that focuses on Joseph Warren and has been helpful during the writing of this article.

\section{References}

1. American Association of Neurological Surgeons: Gunshot Wound Head Trauma. (http://www.aans.org/Patient $\% 20$ Information/Conditions\%20and\%20Treatments/Gunshot $\% 20$ Wound\%20Head\%20Trauma.aspx) [Accessed April 29, 2015]

2. Columbia Neurosurgery: Cranial Gunshot Wounds. (http:// www.columbianeurosurgery.org/conditions/cranial-gunshotwounds/) [Accessed April 29, 2015]

3. Duncan LC: Medical Men in the American Revolution, 1775-1783. Carlisle Barracks, PA: Medical Field Service School, 1931

4. Ellis GE: History of the Battle of Bunker's (Breed's) Hill, on June 17, 1775, from Authentic Sources in Print and Manuscript. Boston: Lockwood, Brooks, 1875

5. Everett AH: Life of Joseph Warren. New York: Harper \& Brothers, 1845

6. Fischer DH: Paul Revere's Ride. New York: Oxford University Press, 1994

7. Forman S: Dr. Joseph Warren: the Boston Tea Party, Bunker Hill, and the Birth of American Liberty. Gretna, LA: Pelican, 2012

8. Frothingham R: The Centennial: Battle of Bunker Hill. Boston: Little, Brown, 1875

9. Frothingham R: Life and Times of Joseph Warren. Boston: Little, Brown, 1865

10. Luntz LL, Luntz P: Handbook for Dental Identification; Techniques in Forensic Dentistry. Philadelphia: Lippincott Williams \& Wilkins, 1973

11. Miller J: The Revolutionary Paul Revere. Nashville: Thomas Nelson, 2010

12. Nelson JL: With Fire \& Sword: the Battle of Bunker Hill and the Beginning of the American Revolution. New York: Thomas Dunne, 2011

13. Nickerson SD, Titus CH: The New England Freemason. Boston: F. Wood, 1874

14. Quatrehomme G, Işcan MY: Gunshot wounds to the skull: comparison of entries and exits. Forensic Sci Int 94:141-146, 1998

15. Sparks J: The Library of American Biography. New York: Harper, 1839

\section{Author Contributions}

Conception and design: Prestigiacomo, Holland, Sabourin. Acquisition of data: Holland, Sabourin. Analysis and interpretation of data: Holland, Sabourin. Drafting the article: Holland, Sabourin. Critically revising the article: all authors. Reviewed submitted version of manuscript: all authors. Approved the final version of the manuscript on behalf of all authors: Prestigiacomo. Administrative/technical/material support: Prestigiacomo, Gandhi, Carmel. Study supervision: Prestigiacomo, Gandhi, Carmel.

\section{Correspondence}

Charles J. Prestigiacomo, 90 Bergen St., Ste. 8100, P.O. Box 1709, Newark, NJ 07101-1709. email: c.prestigiacomo@njms. rutgers.edu. 